\title{
Classical windsock deformity of ruptured sinus of Valsalva: an unusual appearance on transthoracic echocardiography
}

\author{
Iranna Hirapur, ${ }^{1}$ Rajeshwari Mantgol Veeranna, ${ }^{2}$ Navin Agrawal ${ }^{3}$
}

'Department of Cardiology, R L Jalappa Narayana Hrudyalaya, Kolar, Karnataka, India

${ }^{2}$ Department of Opthalmology, R L Jalappa Narayana Hrudyalaya, Kolar, Karnataka, India

${ }^{3}$ Department of Cardiology, Care Hospital, Surat, Gujarat, India

\section{Correspondence to} Dr Navin Agrawal, drnavinagrawal@gmail.com

Accepted 3 May 2014

\section{CrossMark}

\section{To cite: Hirapur I,} Veeranna RM, Agrawal N. BMJ Case Rep Published online: [please include Day Month Yearl doi:10.1136/ bcr-2014-204493

\section{DESCRIPTION}

Aneurysm of sinus of Valsalva is a rare anomaly which arises from a congenital defect of the aortic media or due to damage caused by bacterial endocarditis. It is more prevalent in men and people of Asian descent. ${ }^{1}$

Ruptured sinus of Valsalva (RSOV) is a relatively uncommon cause of acute haemodynamic worsening which is usually seen in young-aged or middle-aged individuals. We present a case of a 23-year-old man who presented with a 20-day history of symptoms of worsening breathlessness; examination showed elevated jugular venous pressure, high volume pulse, S3 and a continuous murmur.

The patient's echocardiogram showed RSOV from the right coronary sinus draining into the right ventricle with classical windsock deformity which is usually very uncommon to be seen on transthoracic echocardiogram (TTE; figures 1-3, videos 1-3). He was referred for surgical correction of the defect at another centre where he underwent successful treatment and has been asymptomatic on follow-up.

Definitive diagnosis of RSOV is usually performed with sufficient accuracy using a TTE but sometimes requires a transoesophageal echocardiogram (TEE) or cardiac catheterisation if the echo images are suboptimal or additional lesions need to be defined especially in cases caused by endocarditis. Details of involvement of other coronary sinuses and the extent of involvement and damage to the surrounding structures especially the aortic valve cusps are best obtained by a TEE. Intraprocedural TEE can also facilitate the

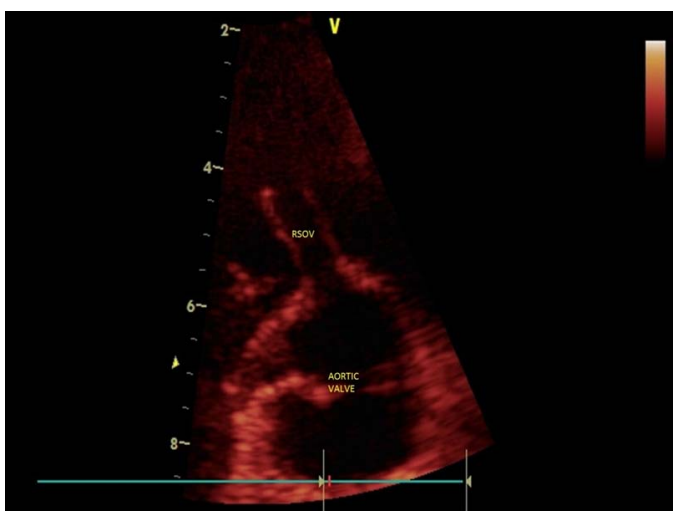

Figure 1 Parasternal short-axis view at the level of the aortic valve showing the classical windsock appearance.

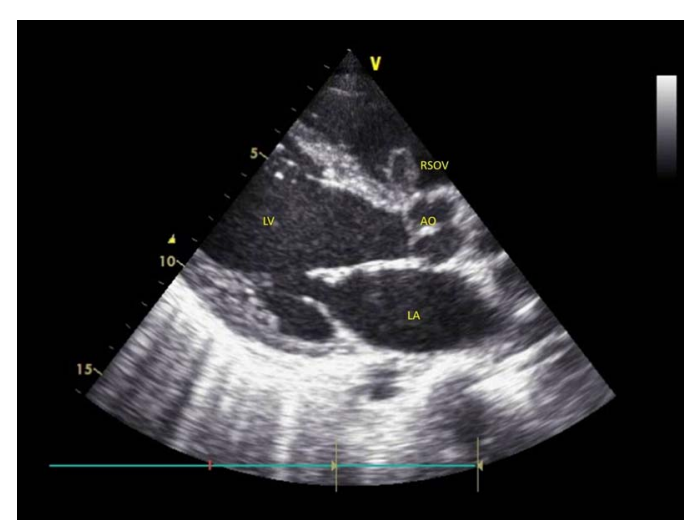

Figure 2 Parasternal long-axis view showing the classical windsock appearance of the ruptured sinus of Valsalva.

performance of percutaneous or surgical closure of defect by assessment of any residual defects after the correction.

The anomaly usually occurs in isolation but may coexist with ventricular septal defect or aortic valve regurgitation in about $30-40 \%$ of patients. ${ }^{1}{ }^{2}$ The most common site of origin of aneurysms is from the right coronary sinus and the most common site of drainage is the right ventricle (70\%).

Uncorrected, the rupture almost invariably causes deterioration in heart function and has a rapid downhill course. Early surgical intervention is the treatment of choice as was performed in this case which led to a successful outcome that was maintained at 3 months of follow-up.

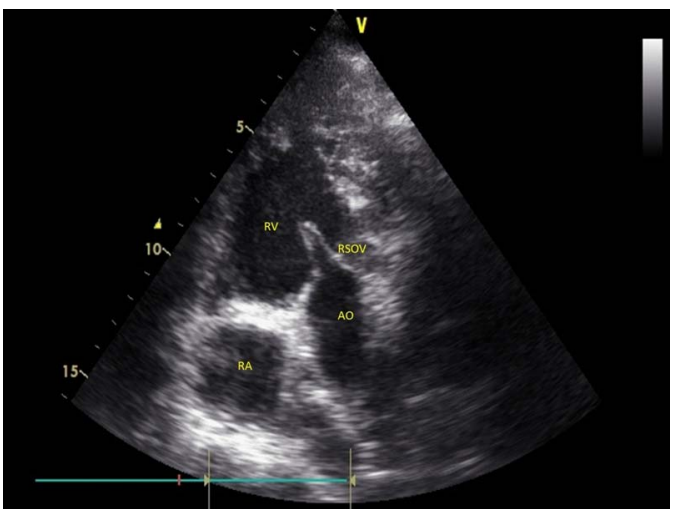

Figure 3 Modified parasternal short-axis view showing the classical windsock deformity. 


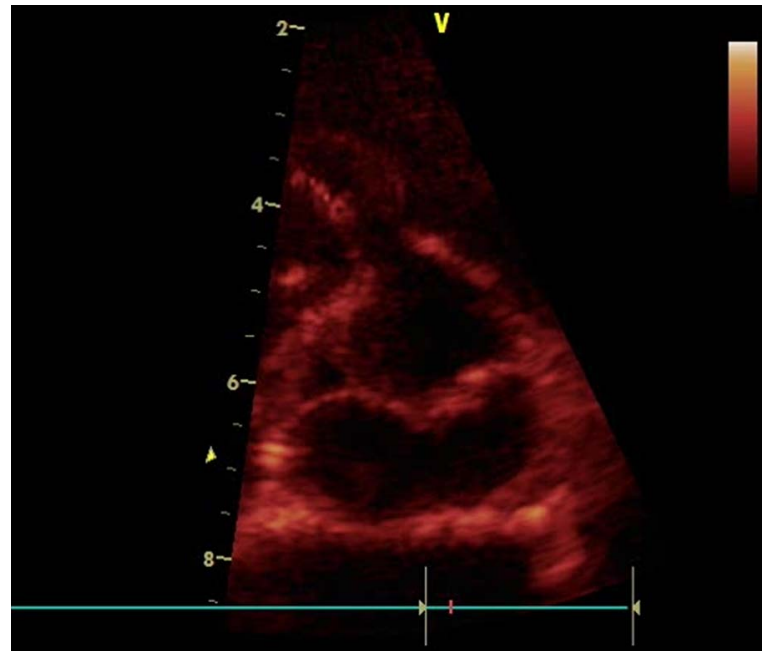

Video 1 Parasternal short axis view showing the classical windsock appearance.

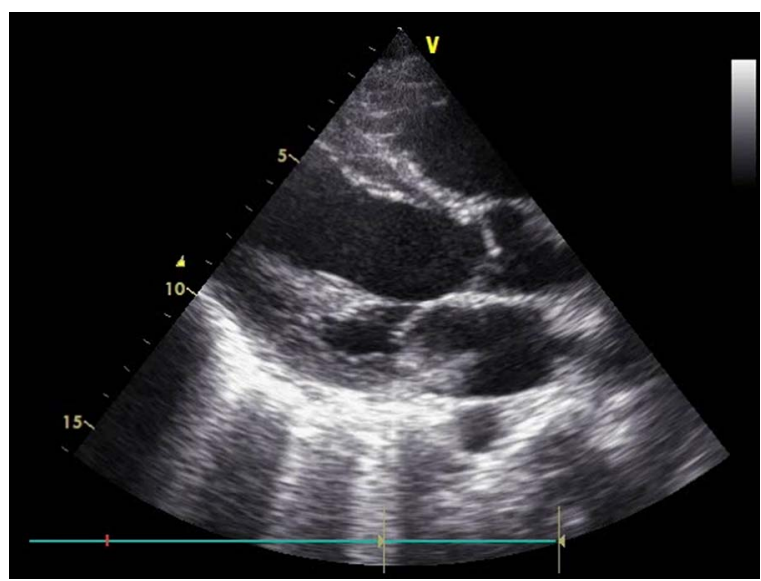

Video 2 Parasternal long axis view showing the classical wind sock appearance of the rupture sinus of Valsalva.

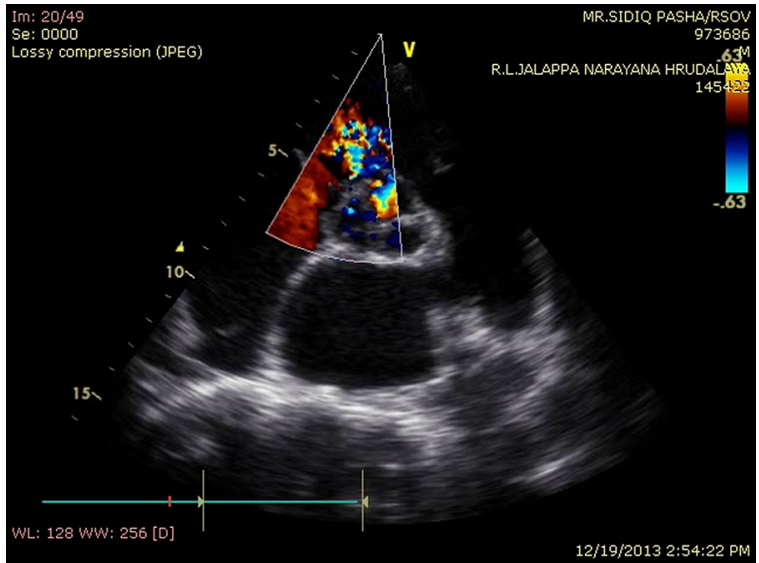

Video 3 parasternal short axis view with colour doppler showing the communication of the ruptured sinus of Valsalva to the right ventricle.

\section{Learning points}

- Ruptured sinus of Valsalva (RSOV) is a relatively uncommon cause of acute haemodynamic worsening which is usually seen in young-aged or middle-aged individuals but one of the most common causes of continuous murmur in them.

- Classical windsock appearance is most commonly seen on transesophageal echocardiogram but it can also sometimes be seen on a transthoracic echocardiogram.

- RSOV if managed appropriately with surgical correction or device closure can be successfully cured and can have an asymptomatic long-term outcome.

Competing interests None.

Patient consent Obtained.

Provenance and peer review Not commissioned; externally peer reviewed.

\section{REFERENCES}

1 Moustafa S, Mookadam F, Cooper L, et al. Sinus of Valsalva aneurysms-47 years of a single center experience and systematic overview of published reports. Am J Cardiol 2007;99:1159-64.

2 Wang ZJ, Zou CW, Li DC, et al. Surgical repair of sinus of Valsalva aneurysm in Asian patients. Ann Thorac Surg 2007;84:156-60.

Copyright 2014 BMJ Publishing Group. All rights reserved. For permission to reuse any of this content visit

http://group.bmj.com/group/rights-licensing/permissions.

BMJ Case Report Fellows may re-use this article for personal use and teaching without any further permission.

Become a Fellow of BMJ Case Reports today and you can:

- Submit as many cases as you like

- Enjoy fast sympathetic peer review and rapid publication of accepted articles

- Access all the published articles

- Re-use any of the published material for personal use and teaching without further permission

For information on Institutional Fellowships contact consortiasales@bmjgroup.com

Visit casereports.bmj.com for more articles like this and to become a Fellow 